\section{Arylsulphate Synthesis and the Arylsulphatases}

During the course of studies on the synthesis of sulphate esters an opportunity was taken to obtain evidence to support the suggestion ${ }^{1}$ that the type II mammalian arylsulphatases (arylsulphatases $A$ and $B)^{\mathbf{2}}$ were unlikely to be directly involved in the synthesis of arylsulphates by particle-free mammalian liver preparations. It has already been pointed out ${ }^{3}$ that the type I arylsulphatase of mammalian livers (arylsulphatase $C$ ) cannot be directly involved in this synthetic process since the enzyme is microsomal in origin and highly insoluble. Similar considerations do not apply to the type II enzymes, however, since although they are mainly associated with the so-called 'light mitochondria', appreciable amounts are always present in preparations of the soluble components of the liver cell4.

The arylsulphate-synthesizing system of mammalian livers is known to involve at least two main steps ; the production of an active form of sulphate (3'-phosphoadenosine-5' $5^{\prime}$-phosphosulphate) and the subsequent transfer of the sulphate group of this compound to a phenolic acceptor via the agency of a specific transferase enzyme. Particle-free rat-liver preparations ${ }^{5}$ of this synthetic system contained appreciable amounts of the type II arylsulphatases. The average activity of the dialysed preparations was such that $1 \mathrm{ml}$. liberated $2 \mu \mathrm{mole}$ nitrocatechol $/ \mathrm{hr}$. at $37 \cdot 5^{\circ}$ from $0.005 M$ dipotassium 2-hydroxy-5. nitrophenyl sulphate (nitrocatechol sulphate) in $0.5 M$ acetate buffer, $p H \mathbf{H} .0$ (conditions favouring arylsulphatase $A$ activity) and $4 \mu$ mole nitrocatechol/hr. from $0.02 M$ nitrocatechol sulphate in $0.5 M$ acetate buffer, $p H$ 6.0 (conditions favouring arylsulphatase $B$ activity). For various reasons ${ }^{2}$ these values can only be regarded as approximations. When fortified ${ }^{\mathbf{6}}$ with adenosine triphosphate and magnesium and sulphate ions and incubated in the presence of $0.05 M$ phosphate buffer, $p H \quad 7.0$, the dialysed preparations were capable of synthesizing approximately $0.1 \mu$ mole $p$-nitrophenyl sulphate, nitrocatechol sulphate or $p$-acetylphenyl sulphate $/ \mathrm{hr}$. $/ \mathrm{ml}$. from the respective parent phenols.

Further purification of the system by ammonium sulphate fractionation according to the directions of Segal ${ }^{5}$ concentrated both the synthetic and the arylsulphatase activities. However, no loss in type II arylsulphatase activity occurred when the system synthesizing $3^{\prime}$-phosphoadenosine-5' -phosphosulphate was destroyed by treatment with glycylglycine ${ }^{6}$ or when the enzyme system responsible for transfer of sulphate from 3 -phosphoadenosine-5'-phosphosulphate to the phenolic acceptor was inactivated by heat treatments. Purified samples of mammalian arylsulphatases $A$ and $B$ also showed no loss in activity when subjected to these inactivation procedures. Addition of these purified samples to the arylsulphate-synthesizing system decreased the activity of the system slightly, while addition of the purified soluble type I arylsulphatase of Alcaligenes metalcaligenes ${ }^{7}$ strongly inhibited the synthetic process. This is not surprising, since the hydrolytic activity of this bacterial enzyme is unaffected by the phosphate and sulphate ions present in the synthesizing incubation mixture whereas the hydrolytic activity of the type II mammalian arylsulphatases is considerably inhibited by these ions.

It seems probable, therefore, that the arylsulphatases cannot be directly concerned in the synthesis of arylsulphates via 3'-phosphoadenosine-5' -phosphosulphate, and these conclusions are supported by the recent observation (Spencer, B., personal communication) that incubation of purified samples of mammalian arylsulphatases $A$ and $B$ with $p$-nitrophenol in the presence of $3^{\prime}$-phosphosdenosine- 5 '-phosphosulphate did not effect any sulphate synthesis.

One of us (H. B.) is grateful to the Medical Research Council for a research assistantship.

H. BAUM

K. S. DoDGSON

\author{
Department of Biochemistry, \\ Physiology Institute, \\ University of Wales, \\ Newport Road, \\ Cardiff.
}

${ }^{1}$ Roy, A. B., Biochem. J., 59, 8 (1955).

${ }^{2}$ Dodgson, K. S., and Spencer, B., Meth. Biochem. A nal., 4, 211 (1957). Dodgson, K. S., Suencer, B., and Thomas, J., Biochem. J., 56, 177 (1951).

4 Dodgson, K. S., Spencer, B., and Thomas, J., Biwchem. J., 59, 29 (1955).

'Segal, H. I., J. Biol. Chem., 218, 161 (1955).

- De Meio, R. H., Wizerkaniuk, M., and Schreibman, I., J. Biol. Chem., 213, 439 (1965).

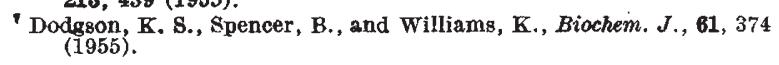

\section{Effect of Chymotrypsin on Caruloplasmin}

INTERest has been shown in the blue, coppercontaining, serum oxidase cæruloplasmin, in particular beceuse of its absence from the blood of subjects with hepatolenticular degeneration ${ }^{1}$. The copper of cæruloplasmin is firmly bound, being non-dialysable at neutral $p \mathrm{H}^{2}$. As part of a study of the mode of linkage of copper to the apo-enzyme, the effect of chymotryptic digestion on cæruloplasmin was inves. tigated.

Caruloplasmin was prepared from the $G 2$ plasma fraction of Kekwick and MacKay ${ }^{3}$ using a modification of the method of Kominz ${ }^{4}$. The final blue material had a broad absorption peak with maximum at about $610 \mathrm{~m} \mu$. Copper content was determined by a diethyldithio-carbamate method ${ }^{4}$ and cæruloplasmin content calculated from Holmberg and Laurell' $\mathrm{s}^{2}$ find. ing of 0.34 per cent copper in cæruloplasmin. Purity was about 70 per cent. An amount of the material containing $20 \mathrm{mgm}$. cæruloplasmin was digested with $3 \mathrm{mgm}$. 'Armour' chymotrypsin in $10 \mathrm{ml}$. 0.05 $\mathrm{M} \mathrm{pH}$ $7 \cdot 5$ sodium phosphate buffer $-0.10 \mathrm{M}$ sodium chloride at $37^{\circ}$ for $22 \mathrm{hr}$. At intervals during digestion, optical density at $610 \mathrm{m \mu}$ was measured and aliquots taken to which tetra-ethyl pyrophosphate was added to inhibit chymotrypsin. Oxidase activity was determined colorimetrically using $\mathrm{N}, \mathrm{N}$-dimethyl $p$-phenylene diamine as substrate (see caption to Fig. I). Nondialysable copper was also determined on three aliquots. Results are shown in Fig. 1. Enzymic activity and the blue $610-\mathrm{m} \mu$ peak decreased during digestion until after $22 \mathrm{hr}$. they were negligible. (The residual absorption at $610 \mathrm{~m} \mu$ after $22 \mathrm{br}$. was no longer a peak and was part of a spread of the normal protein $280-\mathrm{m} \mu$ peak into the visible range. This spread seems characteristic of copper proteins. The 610-m $\mu$ peak of cæruloplasmin is destroyed by ascorbic acid ${ }^{2}$, but the 610-m $\mu$ optical density after $22 \mathrm{hr}$. digestion was found to be unaffected by ascorbic acid.) Non-dialysable copper also decreased during digestion, but after $22 \mathrm{hr}$. it was about half that of the original cæruloplasmin. 